\title{
THE EFFECTIVENESS OF CORPORATE MANAGEMENT TRAINING ON MSME OWNERS OF DHARMA BHAKTI ASTRA FOUNDATION PARTNER
}

\author{
Rizky Surya Ananda*)1, M. Syamsul Maarif*), and Sadikin Kuswanto*) \\ *) School of Business, IPB University \\ Jl. Pajajaran Bogor 16151
}

\begin{abstract}
MSMEs have an important role and strategic in national economic development. The presence of MSMEs can increase workforce absorption, encourage economic growth and distribution of development results. In managing SMEs, skills and knowledge are required by the owner to be able to run the business properly, which can be acquired through the corporate management training program. This research aims to analyze the effectiveness of a corporate management training program by seeing the competencies and performances of business owners after participating in training and creating an effective strategy to increase performance through the corporate management training program. The sample collection method in this study is census sampling from 30 respondents who participated in a management training program. Collected data is analyzed using Structural Equation Modeling - Partial Least Square (SEM-PLS) Smart PLS 2.0 program for all variables and also Analytical Hierarchy Process (AHP). The result of the findings shows that training influenced competency and performance significantly, while competency also influenced performance significantly. The alternative strategy that becomes a priority is to adjust the training topic specifically according to business owner needs. This study will be useful for institutions or training organizers for MSMEs in the future.
\end{abstract}

Keywords: management training, competencies and performances, MSMEs, SEM-PLS, AHP

\begin{abstract}
Abstrak: UMKM memegang peranan penting dan strategis dalam pembangunan ekonomai nasional. Keberadaan UMKM dapat menambah penyerapan tenaga kerja, mendorong pertumbuhan ekonomi, dan distribusi hasil pembangunan. Dalam mengelola UMKM, diperlukan kemampuan dan pengetahuan dari pemilik usaha agar dapat menjalankan usaha tersebut dengan benar yang bisa didapat pelatihan manajemen perusahaan. Tujuan dari penelitian ini adalah untuk menganalisa efektifitas pelatihan manajemen perusahaan dengan melihat kompetensi dan kinerja pelaku usaha setelah mengikuti pelatihan serta membuat strategi efektif untuk meningkatkan kinerja melalui program pelatihan manajemen perusahaan. Metode pengumpulan sampel dalam penelitian ini adalah sampling sensus yaitu seluruh peserta yang telah mengikuti pelatihan manajemen perusahaan yang berjumlah 30 responden. Data yang terkumpul dianalisis menggunakan Structural Equation Modeling Partial Least Square (SEM-PLS) Lisrel 8.8 dan porgram SPSS 24.0 untuk semua variabel serta Analytical Hierarchy Process (AHP). Hasil temuan menunjukkan bahwa pelatihan berpengaruh signifikan terhadap kinerja dan juga kompetensi, serta kompetensi berpengaruh signifikan terhadap kinerja. Selain itu, alternatif strategi yang menjadi prioritas utama adalah menyesuaikan spesifikasi materi pelatihan sesuai dengan kebutuhan pelaku usaha. Studi ini berguna untuk institusi atau penyelenggara program pelatihan bagi UMKM di masa depan.
\end{abstract}

Kata kunci: pelatihan manajemen, kompetensi dan kinerja, UMKM, SEM-PLS, AHP

\footnotetext{
${ }^{1}$ Corresponding author:

Email: rizky.surya@outlook.com
} 


\section{INTRODUCTION}

The development of a country is untied from its economic development, including Indonesia, which sources quite a lot of natural and human resources that can be reliable. The economic development must be felt directly by the citizens, and the construction of infrastructure also needs to be improved. Global competition can be thoroughly felt to the deepest layer of society level, and the world economy index will influence Indonesia as a country highly consumptive society.

Micro, Small, and Medium Enterprise (MSME) have an essential role and strategic in national economic development. Aside from economic development and workforce absorption, the MSME role is to distribute constructions result. MSME has proven itself unaffected by the crisis. When the crisis struck during $1997-1998$ in Indonesia, only MSME can withstand. The number of MSME even after 1997 - 1998 keeps increasing to 59 million MSME spread around Indonesia. MSME also contributes to GDP as high as $62.57 \%$. The data from the Ministry of Corporation and Small Medium and Enterprise also shows that MSME keeps increasing by 2 to 5 percent every year from 2011 to 2017 .

This fast-paced development of MSME in Indonesia has made citizens follow and create their businesses. To build a business that can compete and sustain on the market, surely need skills or good understanding from the entrepreneur such as financial, human resource, marketing, and product management. Although the number of MSME in Indonesia keeps increasing, there are quite a few issues that entrepreneurs faced. One of them is productivity, which can be seen from the contribution to GDP. Compared to other countries, especially in South East Asia, the contribution percentage from MSME in Indonesia is still low. This implies that the contribution can still be increased by improving the efficiency, effectiveness, entrepreneurial skills, and financial support for MSME.

To improve this situation, the government and private sector tried to support entrepreneurs to be able to build their businesses that can sustain and compete on the market through various programs. These programs can be financial support, construction, supervision, and training programs for new entrepreneurs. One of the preferable programs for these new entrepreneurs is training programs, which gives an understanding of business management that can increase their competencies and work performance.

Dharma Bhakti Astra Foundation (YDBA) is an organization that thrives on improving the quality of MSME in Indonesia. Since its first time founded in the year 1980, YDBA has supervised 10,894 MSME and absorbs 68,030 workforce and still counting. To achieve their target, YDBA aware that they need to improve their partner or business owner managerial skills by implementing a training program. Although YDBA is acknowledged with their proven supervision to their partner, YDBA still wanted to improve their managerial skill by collaborating with another organization with the same goals, The Association for Overseas Technical Cooperation and Sustainable Partnerships (AOTS). Through this collaboration, it is expected that entrepreneurs from YDBA could learn from AOTS's corporate management training program.

he Association for Overseas Technical Cooperation and Sustainable Partnerships (AOTS) has organized various kinds of management training, not only in Japan but also in developing countries. One of its management training programs is corporate management. During this training, participants were taught several topics about management skills that are required by entrepreneurs such as financial, human resource, marketing, and product management. The methods of teaching used were theories, practice, assignments, company visits, site visits, and final presentation with the end target of an increase in entrepreneurs managerial skills, competencies, and work performance.

To acquire this target, a training program should be effective for individuals. Therefore, an evaluation of a training program is also required after the implementation of training to see whether it is effective for individuals or not (Kirkpatrick, 2016). Kirkpatrick (2016) implies that to be able to know the overall effectiveness of training required four-step evaluation has been done. The four phases of evaluation are reaction, learning, behavior, and result.

According to Halawi and Haydar (2018) the training can increase work performance through changes in knowledge and skills. Knowledge and skills correlates to competency, where Posuma (2013) defines competency is an ability to do a job based on their skills and knowledge. Thus, to identify whether a work performance and competency has increased a training evaluation is required. 
Based on previous researches, Training effectiveness influenced positively and significantly on competencies on private teachers (Ayuningtyas, 2010). Competencies then can also contribute significantly and positively to employee performance (Ataunur and Ariyanto, 2015). An effective training program can be seen through positive changes in behavior and learning by the participants (Fry, 2011). Specific training for immigrant candidates can also increase their knowledge, skills, and follow organization goals (Kusbiantoro, 2015).

Although some research finds training programs can increase competencies and work performance, research by Nurjanah (2006) shows that the training program was not fully effective for employees, and Safitri (2013) implies in her research that work performance is not significantly influenced by training. Several other researchers also found that training partially positively and significantly influences employee performance (Sianturi, 2018). These differences prove that training is still an exciting topic, especially when it comes to corporate management training.

Mukata et al. (2018) implies that corporate management training and entrepreneurial skills can fulfill the needs of the entrepreneur in Nambia. In his research, Mukata et al. (2018) analyzed the effectiveness of a corporate management training program that was conducted by SME Service Providers in Namibia using a questionnaire given to the 60 participants.

The goal of this research is to analyze the influence of training on competency, the influence of training on work performance, and the influence of competency on work performance. The research design used in this study is hypothesis testing, where all collected data will be tested its significancies. The research approach used in this research is quantitative studies. To improve the result of this research, the researcher will analyze the most strategy that can be implemented for future corporate management training programs.

\section{METHODS}

Data collection was taken from February to June 2019 in AOTS, who held a management training program for
YDBA SMEs. Respondents are training participants who participated in a corporate management training program in 2018. The research uses primary data from a questionnaire which distributed to participants after the training program finished and also a short unstructured interview with ex-trainees to gain a deeper understanding of their perception from corporate management training. Questionnaires were given to extrainees after two years of their participation. Secondary data acquired from various literature, company archives, books that are relevant to the researched topic, previous researches, internet media, and other literature from this research.

Sampling methods used in this research is nonprobability sampling with sampling census technique. According to Sugiyono (2013), this sampling technique is used for a relatively small population where data will be collected. Therefore, all populations will be the sample. Collected data is analyzed using Structural Equation Modeling - Partial Least Square using software SmartPLS 2.0. Likert scale on a scale of 1 to 5 were used to measure indicator variable with scale $1=$ Strongly disagree; $2=$ Disagree; $3=$ Neutral; 4 $=$ Agree; and $5=$ Strongly agree. Descriptions and measurements of variables, as shown in Table 1. Based on the explanation above, the research model is shown in Figure 1.

Table 1. Operationalization variables

\begin{tabular}{lll}
\hline Latent Variable & $\begin{array}{l}\text { Indicator } \\
\text { Variable }\end{array}$ & Symbol \\
\hline Latent Exogen Variable & & X1 \\
Training (X1) & Reaction & X2 \\
(Kirkpatrick, 2016) & Learning & X3 \\
& Behavior & X4 \\
& Results & \\
Latent Endogen Variable & & Y11 \\
Competencies (Y1) & Knowledge & Y12 \\
(Hutapea and Thoha, & Skills & Y13 \\
2008) & Attitude & Y21 \\
Performance (Y2) & Quality of work & Y22 \\
(Robbins, 2006) & Quantity of work & Y23 \\
& Time accuracy & Y24 \\
& Work effectiveness & Y25 \\
\hline
\end{tabular}




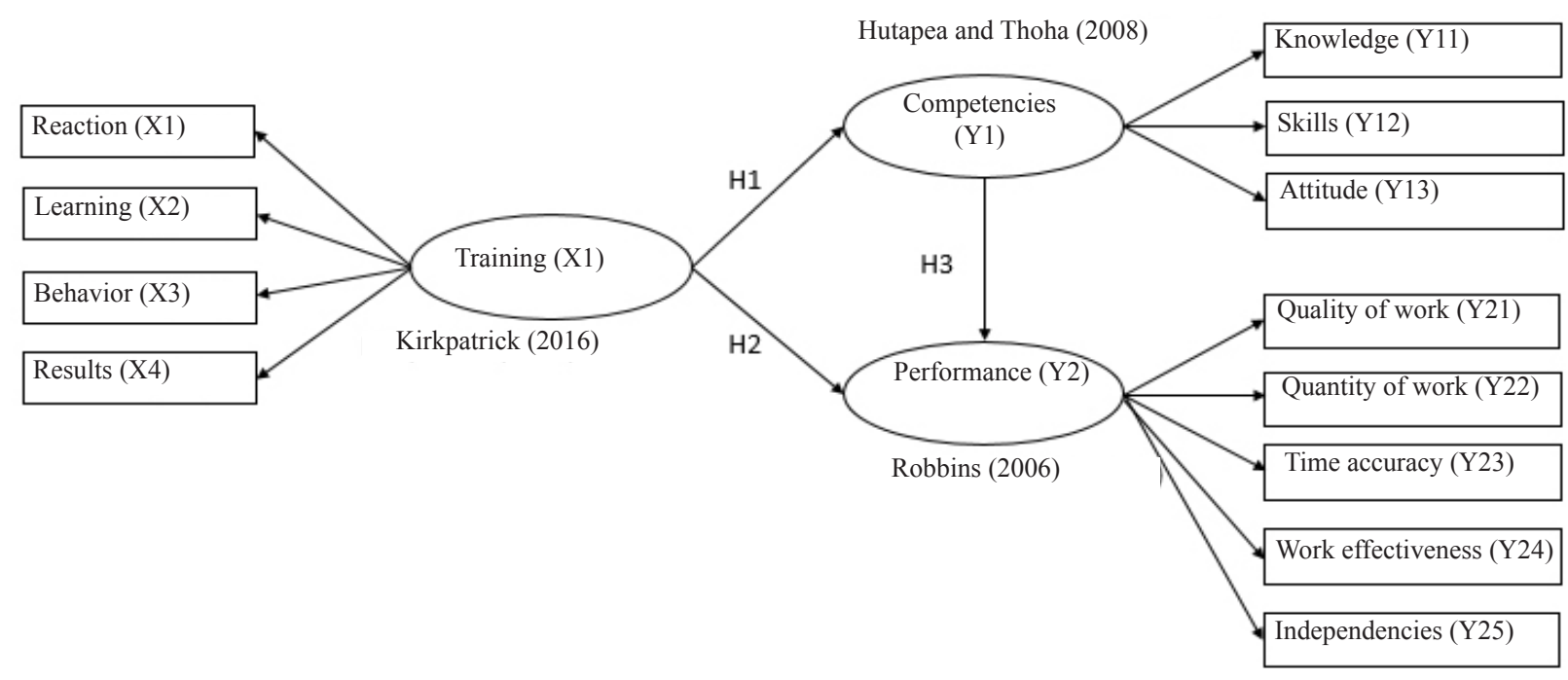

Figure 1. Research model

This research also used Analytical Hierarchy Process with expert choice software to find the most suitable strategy that can improve the management training program for YDBA SME. AHP is one of the methods used in the decision-making process by concerning perception, preference, experience, and intuition factor. AHP logically combined values and personal points. In this research, the AHP hierarchy structure will be prepared by the AOTS training program coordinator after a literature review and consulting with experts, general manager, and instructor. The AHP hierarchy structure is based on factors that affect effective training which was also used as reaction dimension in training variables at the SEM-PLS model. Under reaction dimension, according to Kirkpatrick (2016), indicators that can be used to measure the reaction are methods, instructors, facilities, and time. After the factors have been decided, we used it to determine the further criteria which are actors, goals, and alternative strategy. And also based on the result of SEM-PLS, we formulated the alternative strategy that can be chosen properly. The formulation strategy is shown in Figure 2.

A questionnaire table was distributed based on the strategy formula with priority arrangement. Each element included in the hierarchy should have the weight known to each other, the purpose is to identify the level of importance of each side in the issue on the criteria and hierarchy structure or the system as a whole. Difference scale in numeric scale to show to the level of importance and the dominance of one element to another element. Tabel 2 shows the paired measurement scale in the AHP process.
The hypotheses on this research are as follows:

H1: Corporate management training program has a significant and positive influence on competencies

$\mathrm{H} 2$ : Corporate management training program has a significant and positive influence on performance

H3: Competencies has a significant and positive influence on performance

\section{RESULTS}

\section{Respondent Characteristics}

The result of this research indicates that from 30 respondents, 25 were male and 5 were female. These dominant numbers in male gender were probably caused by a reference in Indonesian culture where male as head of the family should run the business. The average age of participants was 41 to 50 years old, with 12 participants followed by 31 to 40 years old and more than 50 years old with 7 participants each. In many countries, 41 to 50 years old are quite common age where individuals are at their past primary and have long working experience with proper financial support to run a business. The level of education from the participants was a bachelor's degree with 20 participants or $67 \%$ of total participants. The level of education gives an individual an ability to gain more insight and critically that made them capable of starting a business. Experiences in Bachelor's degrees can not be obtained from a lower education level. As for their business classification, the researcher classifies based on their number of employees in their business. There are 19 participants from small enterprise, 7 from middle 
enterprise, and 4 from micro-enterprise. Dharma Bhakti Astra Foundation, as a platform for entrepreneurs, only prioritizes small enterprises that are still new and need more supervision by YDBA. While the middle and large companies will not require supervision by YDBA, they are less concerned.

The corporate management training program is implemented once a year by YDBA from 2015 to 2019. Every implementation, topic, and cases given to participants is always the same, just with different participants. Rating levels from the respondent on training were divided into four dimensions, which are reaction, learning, behavior, and result. The ratings were divided into three categories, which are low with Likert scales 1 to 2 (strongly disagree and disagree), average with Likert rating scale of 3 (neutral), and high with Likert scales of 4 to 5 (agree and strongly agree). A corporate management training program organized by AOTS received an excellent response from the participant. Table 3 shows the respondent's answer regarding the training dimension.

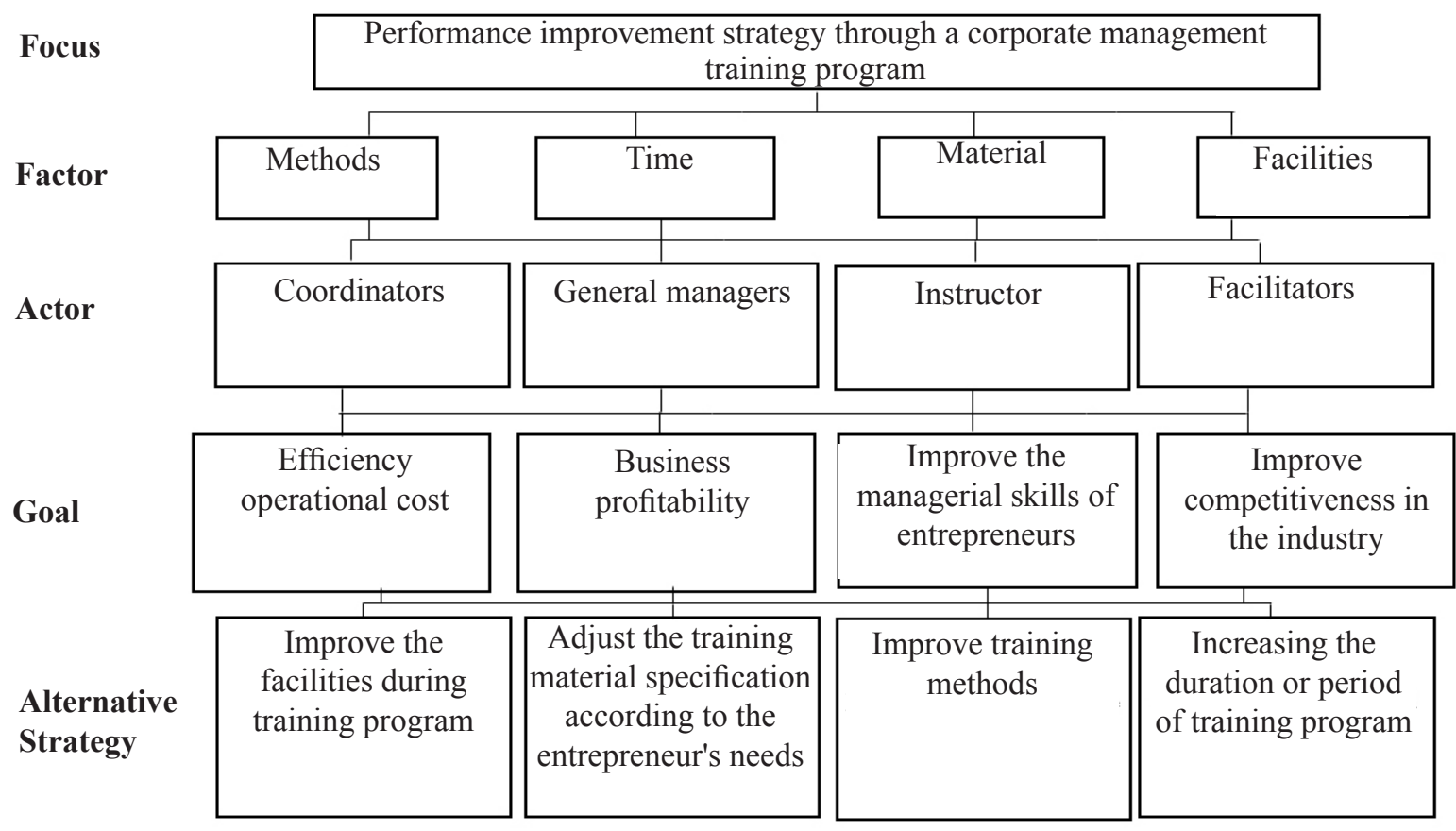

Figure 2. AHP strategy formulation

Table 2. Paired comparison measurement scales

\begin{tabular}{|c|c|c|}
\hline Importance Level & Definition & Remarks \\
\hline 1 & Equally Important & Both elements have the same influence. \\
\hline 3 & Quite more important to each other & $\begin{array}{l}\text { Pengalaman dan Experience and measurement have one small } \\
\text { dominance other elements }\end{array}$ \\
\hline 5 & Quite important & $\begin{array}{l}\text { Experience and decision shows the success of one activity } \\
\text { than another one }\end{array}$ \\
\hline 7 & Very important & $\begin{array}{l}\text { Experience and decision show strong likeliness of one activity } \\
\text { than another }\end{array}$ \\
\hline 9 & Absolutely more important & $\begin{array}{l}\text { One element is absolutely liked than other paired with the } \\
\text { highest confidence }\end{array}$ \\
\hline $2,4,6,8$ & $\begin{array}{l}\text { The middle value between two values } \\
\text { of the decision }\end{array}$ & If a compromise is necessary \\
\hline Reciprocal & Reverse & $\begin{array}{l}\text { If element I has one of value in comparison scale } 1-9 \text { that } \\
\text { has been set by Saaty than element J. then J has the reversal } \\
\text { when compared to element } i\end{array}$ \\
\hline Ratio & $\begin{array}{l}\text { The ratio that acquired directly from } \\
\text { the measurement }\end{array}$ & \\
\hline
\end{tabular}


Based on Table 3, the research result shows that participants had a very good reaction to the training given by YDBA. Participants strongly agree that the training given have already met their needs, and also the training support such as instructor, time, room size, and modules. Table 4 shows the respondents' perception of their competencies dimension after participating in the management training program.

We can see that the respondent score for competencies is good, with a score of 4.150. In each indicator, knowledge contains information about their own company, management, and people in the organization. For performance score from the respondent is shown in Table 5.

The respondent score regarding their work performance is good. The highest score was to work quality and work effectiveness. It is believed that during corporate management training, the instructor gave clear instructions or theories to improve their work quality and effectiveness the most. However, their independencies are at the lowest level due to their position as an owner or director who needs their subordinates to do the job for them.

\section{SEM-PLS Analysis}

After all data collected, it will be processed with structural equation modeling (SEM) with estimation method partial least square (PLS). There are two types of measurement in structural equation modeling. They are the outer model and inner model. The measurement model explains variance proportion for each variable indicator that can be explained in the latent variable. Through the measurement model, it can identify which indicator is dominant in forming latent variables. After the measurement analysis model from each latent variable is done, the breakdown of the structural model will be implemented. The structural model will study the influence of each exogenous latent variable on endogenous latent variables. The structural model will be evaluated with R-square; changes in R-square value can be used to measure latent variable influence whether it has substantive influence or not. Evaluation result will be acquired by path diagram full model influence from training and competencies on performance.

\section{The Goodness of Fit Model Measurement Test}

\section{Convergent Validity}

This testing phase was done to measure whether every indicator can reflect their latent variables. The value that was used on this validity convergent is the loading factor value from each dimension. An indicator that has a loading factor less than 0,50 is considered unable to reflect the latent variable. The result of the loading factor from this research is shown in Figure 3.

Based on Figure 3, the loading factor value from each indicator in the training variable is more than 0.50 . Therefore, it can be concluded that all indicators in the training variable are valid as a measurement tool. It can also be implied that all indicators can reflect the variables in this research.

Reliability Test

Table 3. Result of training dimension respondent answers

\begin{tabular}{lcc}
\hline Indicator & Average score & Criteria \\
\hline Reaction & 4.3879 & Very good \\
Learning & 4.0667 & Good \\
Behavior & 4.3556 & Very good \\
Result & 4.3111 & Very good \\
Average score & 4.2803 & Good \\
\hline
\end{tabular}

Table 4. Result of competencies dimension respondent answer

\begin{tabular}{lcc}
\hline Indicator & Average score & Criteria \\
\hline Knowledge & 4.0667 & Good \\
Skills & 4.05 & Good \\
Attitude & 4.333 & Very good \\
Average score & 4.1500 & Good \\
\hline
\end{tabular}

Table 5. Result of performance dimension answer from respondents

\begin{tabular}{lcc}
\hline Indicator & Average Score & Criteria \\
\hline Work Quality & 4.1333 & Good \\
Work Quantity & 4.1111 & Good \\
Time Discipline & 4.1556 & Good \\
Independencies & 3.8677 & Good \\
Work Effectivity & 4.1333 & Good \\
Average Score & 4.0800 & Good \\
\hline
\end{tabular}




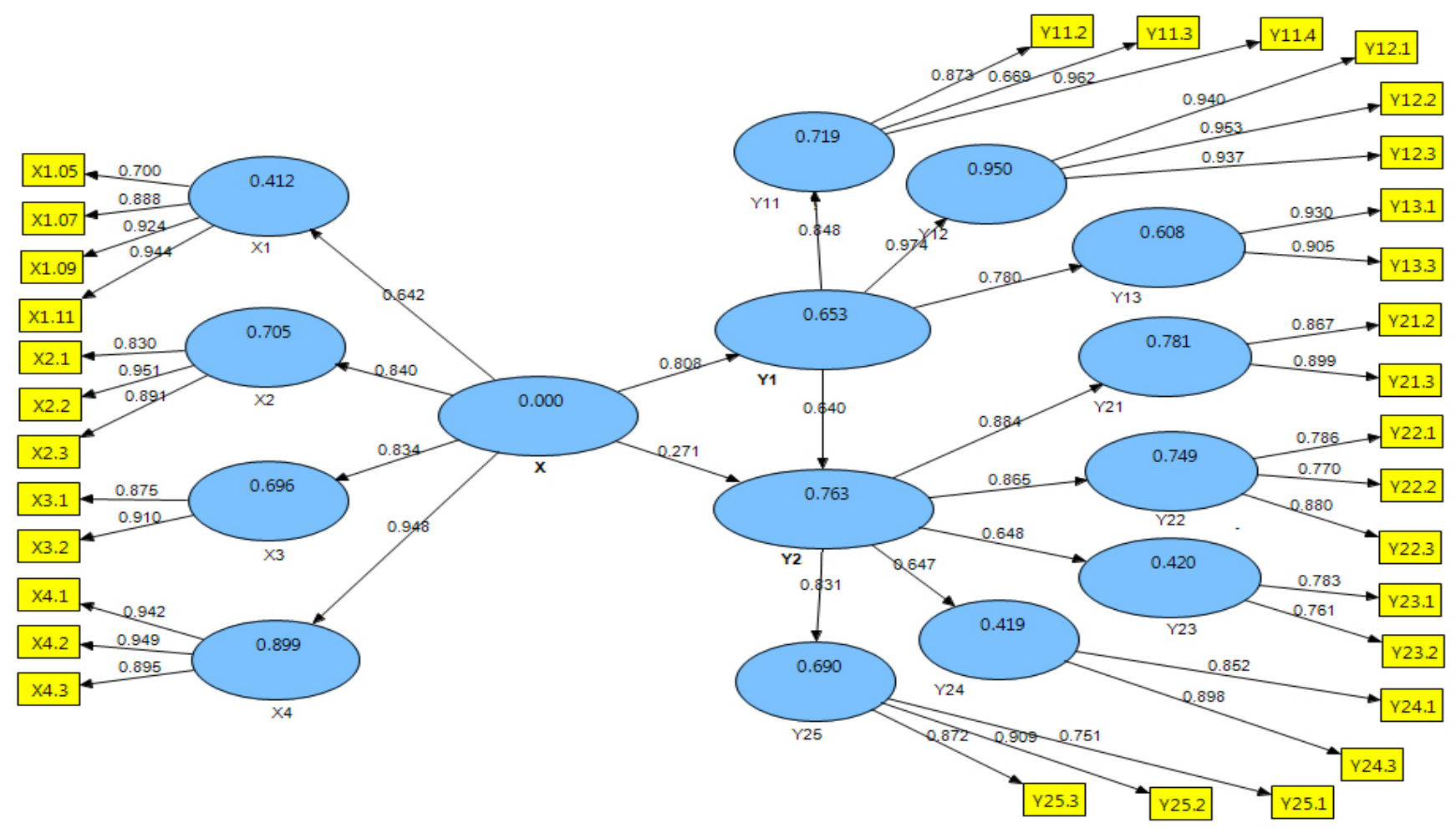

Figure 2. AHP strategy formulation

Reliability Test is done by seeing composite reliability value. Before that, validate the test needs to be done first by using AVE value. Based on Table 6, the loading factor value can identify AVE value from all dimension that has value more than 0.5 . Therefore it can be implied that overall average information in each indicator can reflect through each dimension bigger than 50\%. Highest AVE value in AVE value table and composite reliability is on $\mathrm{X}$ dimension weight as $\mathrm{X}$. That value means, average $83 \%$ information in each indicator can be reflected through dimension as supporting facility. The reliability test can then be tested by looking at the composite reliability value. In this study, the composite reliability that counted as reliable is higher than 0.70 . Composite reliability value shows higher than 0.70 . This implies that indicators have consistency level in measuring it each dimension.

\section{Discriminant Validity Test}

The discriminant validity test is done with a principle that different measurements (manifest variables) construct should not correlate highly (Ghozali, 2008). The discriminant validity test in Figure 4 shows that all indicators have a cross-loading value higher than its latent variable compared to other latent variables. It can be stated that the model has fulfilled discriminant validity. Aside from that, the discriminant validity test can also be seen through a comparison between $\checkmark$ AVE with coefficient correlation value with the latent variable. Overall $\sqrt{ }$ AVE value higher than the correlation value between the latent variable means that model has fulfilled discriminant validity.

\section{Determinant Coefficient}

The determinant coefficient is used to measure changes in the variation level independent variable on the dependent variable. Table 7 shows that R2 on performance is 0.764 which means $76 \%$ percent of this variable can be explained by training and competency variable, $24 \%$ of performance variable is explained by another variable outside this model. The R2 value on the competency variable is 0.653 which means $65 \%$ of this variable can be explained by training variable, the other $35 \%$ can be explained by another factor outside this model.

The effect of training on competency

The result of bootstrapping on Table 8 shows that training has a significant influence on competency on a standard of $5 \%$ because the t-statistic value is $11.75>$ $\mathrm{t}$-table (1.96). The influence of training on competency is 0.808 which means the higher increase of training which reflected by the reaction, learning, behavior, and result then competency will also increase. These 
results are consistent with the study by Ayuningtyas (2010) about the effectiveness of training on improving the competency of lecturer at Bintang Pengajar with partial least square. The result of her study indicates that training had a positive and real effect on the competence of lecturer at Bintang pengajar who have finished participating in a training program.

The effect of training on performance

Based on Table 9, training has a significant influence on performance on a standard of $5 \%$ because t-statistics (1.99) > t-table (1.96). The influence of training on performance is 0.271 which means the higher increase of training reflected by the reaction, learning, behavior, and results then performance will also increase. This result is consistent with the study by Fry (2011) about the influence of training on the performance of SMEs in the food industry. His study shows that training has a positive and significant influence on the performance of the food industry SMEs, especially on behavior and results from the indicator. Aside from that, the study by Sianturi (2018) about the effect of training and development on employee performance at PT Bank Mandiri Tbk Imam Bonjol Medan branch also implies that training partially influenced employee performance significantly and positively. Based on researcher short interview with an entrepreneur that participated in YDBA corporate management training, their abilities and attention to details in their companies have increased, also the way the entrepreneurs handle their job becomes more arranged that increased their work productivity.
Table 6. AVE value and composite reliability firstorder analysis

\begin{tabular}{lcc}
\hline & AVE & Composite Reliability \\
\hline X1.Reaction & 0.756 & 0.924 \\
X2.Learning & 0.796 & 0.921 \\
X3.Behavior & 0.797 & 0.887 \\
X4.Results & 0.863 & 0.950 \\
Y11.Knowledge & 0.712 & 0.879 \\
Y12.Skills & 0.890 & 0.960 \\
Y13.Attitude & 0.842 & 0.914 \\
Y21.Work Quality & 0.780 & 0.876 \\
Y22.Work Quantity & 0.662 & 0.854 \\
Y23.Time dicipline & 0.596 & 0.747 \\
Y24.Independency & 0.766 & 0.868 \\
Y25.Effectiveness & 0.717 & 0.883 \\
\hline
\end{tabular}

Table 7. Determinant coefficient values

\begin{tabular}{lc}
\hline & R Square \\
\hline Competency & 0.653 \\
Performance & 0.763 \\
\hline
\end{tabular}

Table 8. T-statistic value and path coefficient of training variable on competency variable

\begin{tabular}{lcc}
\hline & Path Coefficient & T-Statistic \\
\hline $\begin{array}{l}\mathrm{X} 1 \text { Training } \rightarrow \text { Y1 } \\
\text { Competency }\end{array}$ & 0.808 & $11.75^{*}$ \\
\hline
\end{tabular}

Table 9. T-statistic values and path coefficients of training on performance

\begin{tabular}{lcc}
\hline & Path Coefficient & T-Statistic \\
\hline $\begin{array}{l}\text { X1.Training } \rightarrow \text { Y2 } \\
\text { Performance }\end{array}$ & 0.271 & $1.99^{*}$ \\
\hline
\end{tabular}

\begin{tabular}{|c|c|c|c|c|c|c|c|c|c|c|c|c|}
\hline & X1 & $\mathrm{X} 2$ & $\mathrm{X} 3$ & $\mathrm{X} 4$ & Y11 & Y12 & Y13 & Y21 & Y22 & Y23 & Y24 & $\mathrm{Y} 25$ \\
\hline X1.Reaction & 0.869 & & & & & & & & & & & \\
\hline X2.Learning & 0.262 & 0.892 & & & & & & & & & & \\
\hline X3.Behavior & 0.467 & 0.593 & 0.893 & & & & & & & & & \\
\hline X4.Results & 0.464 & 0.805 & 0.770 & 0.929 & & & & & & & & \\
\hline Y11.Knowledge & 0.272 & 0.849 & 0.507 & 0.805 & 0.844 & & & & & & & \\
\hline Y12.Skills & 0.529 & 0.588 & 0.399 & 0.716 & 0.768 & 0.943 & & & & & & \\
\hline Y13.Attitude & 0.543 & 0.470 & 0.458 & 0.647 & 0.388 & 0.747 & 0.917 & & & & & \\
\hline Y21.Work Quality & 0.237 & 0.624 & 0.477 & 0.722 & 0.786 & 0.619 & 0.446 & 0.883 & & & & \\
\hline Y22.Work Quantity & 0.371 & 0.626 & 0.610 & 0.750 & 0.603 & 0.481 & 0.531 & 0.770 & 0.814 & & & \\
\hline Y23.Time dicipline & 0.296 & 0.268 & 0.542 & 0.453 & 0.313 & 0.525 & 0.730 & 0.540 & 0.462 & 0.772 & & \\
\hline Y24.Independency & -0.023 & 0.594 & 0.267 & 0.594 & 0.438 & 0.380 & 0.575 & 0.350 & 0.541 & 0.398 & 0.875 & \\
\hline Y25.Effectiveness & 0.304 & 0.632 & 0.412 & 0.738 & 0.827 & 0.896 & 0.555 & 0.705 & 0.546 & 0.400 & 0.411 & 0.847 \\
\hline
\end{tabular}

Figure 4. Result of discriminant validity test 
The effect of competency on performance

Competency has a significant influence on performance because t-statistics (5.07) is higher than t-table (1.96). Based on the path coefficient on Table 10, competency influenced performance by 0.640 which means the better the competency which reflected by knowledge, skills, and attitude then performance will also increase. These results are consistent with the study by Ataunur and Ariyanto (2015) about the effect of competency and training on employee performance at PT. Adaro Energy Tbk. Their result shows that competency contributed significantly and strongly positive on performance with multiple linear regression. The researcher also observed the competency of participants after their training where they have finally know what is their company management philosophy, financial situation, and how to market their product properly. They also stated that their style of approach in communicating with their employees had increased after learning from YDBA corporate management training.

\section{Result of AHP vertical analysis}

After the decision-making tree has been created based on literature review and the opinions of 4 experts who involved in corporate management training, weight measurement will be done from each criterion so that the most effective strategy in developing participant managerial skill through a training program can be found. Weight measurement was done by using Expert Choice 2000 Software. Expert Choice 2000 is a supporting software that user friendly and gives a high contribution to the successful AHP method because it combined graphics use intuitively, automatic priority calculation, and has several ways to process sensitivity analysis (Ishizaka and Labib, 2009). The combined hierarchy analysis from 4 experts vertically is explained in Figure 5.

Analysis of actor elements

Actors that become the first priority is the Instructor weighted 0.386 . This can be seen directly because the Instructor is more involved with the participant during the training program was implemented. The instructor holds bigger responsibility than other actors such as making sure that participants can understand the presented topics, answers to the question concerning topics, until controlling the room to keep participants focused on the presentation during the training program.
The following priority in order are coordinators (0.247), general managers $(0.224)$, and facilitators $(0.142)$.

Analysis of factor element

The most prioritized factor from Figure 5 is training materials or topics. The suitability of material $(0.520)$ according to the needs of the participant will always be the first attention of training organizers. On one of this corporate management training, the material given covers many managerial aspects such as marketing management, human resource management, financial management, to management philosophy. Most of the entrepreneurs especially YDBA members, run their company without direction or clear goals so that YDBA started to direct this entrepreneur by giving corporate management training programs through AOTS as a training organizer. Based on the researcher interview with the ex-participant, it can be said that the recent corporatemanagement training program was toogeneral, the topics were quite common and could be learned by themselves elsewhere. They required a specific and deep understanding of one topic they find more interesting to learn. For example, Japanese management or culture that can keep Japanese companies sustainable in the long run. The other priority from factor elements in order are methods, facilities, and time with weight $0.247,0.142$, and 0.103 .

\section{Analysis of goal element}

The most prioritized strategy for the element of the goal is to improve the managerial skills of entrepreneurs weighted 0.415 . This is consistent with the main goal of this corporate management training which organized by AOTS, where the result expected from this program is participant can make a decision or solve managerial issues in their respective company. Every entrepreneur is expected to manage their company properly to achieve that goal require an owner with wide insight for business sustainability. The following priority in goal elements is to improve competitiveness in the industry weighted 0.245 , efficiency operational cost weighted 0.179 and business profitability with weight 0.161

Table 10. T-statistic value and path coefficient of competency on training variable.

\begin{tabular}{lcc}
\hline & Path Coefficient & T-Statistic \\
\hline Y1 Competency $\rightarrow$ & 0.640 & $5.07^{*}$ \\
Y2 Performance & & \\
\hline
\end{tabular}




\section{Analysis of alternative strategies}

The alternative strategy that becomes the main priority is to adjust the training material specification according to the entrepreneur's needs weighted 0.393. Based on a discussion with the experts, it is true that the current material for the participants does not match with the participant's needs. Participants prefer a more deep understanding of a specific material rather than general information of management theories itself. Therefore, training organizers have to improve the corporate management training program by choosing a specific issue. The issues can be marketing management in a deeper understanding or designing a more intensive training program of management issues. The second alternative strategy is to improve training methods with a weight of 0.310 . Followed by increasing the duration or period of training program weight 0.227 and improve the facilities during training program weighted 0.07 . Improving the facility does not seem to be necessary by the experts because they think AOTS's current facility is already at the best level to support the participant's learning process.

\section{Managerial Implications}

After analyzing this research, it is noted that corporate management training can influence the competencies and performance of YDBA MSME entrepreneurs. Based on these findings, it can be formulated managerial implications as follows:

- To improve the performance of YDBA entrepreneur through corporate management training, the first priority in factor element is materials, Meanwhile, the actor that has the main role is the instructor. Goals element that becomes the first priority is to improve the managerial skills of the entrepreneur and the most prioritized strategy is to match training materials specification according to entrepreneur needs.

- AOTS need to adjust material specification according to participant needs. To identify the participant needs, a survey has to be done on training candidate that is YDBA MSME through questionnaire dispatch, group discussion, or even by doing Training Need Analysis. After their needs have been identified, related to training candidate corporate management the participant that time will design a training program that is expected to match the needs of the participant. Besides, it is also necessary to determine how the material should be conveyed by the instructor to participants, such as a combination of theory, practice, visits, and assignments. After material and training methods adjusted properly, then time and facilities can follow. So far AOTS is considered to have given enough training program time, which is 10 working days and is supported by facilities that can support the effectiveness of the training program itself.

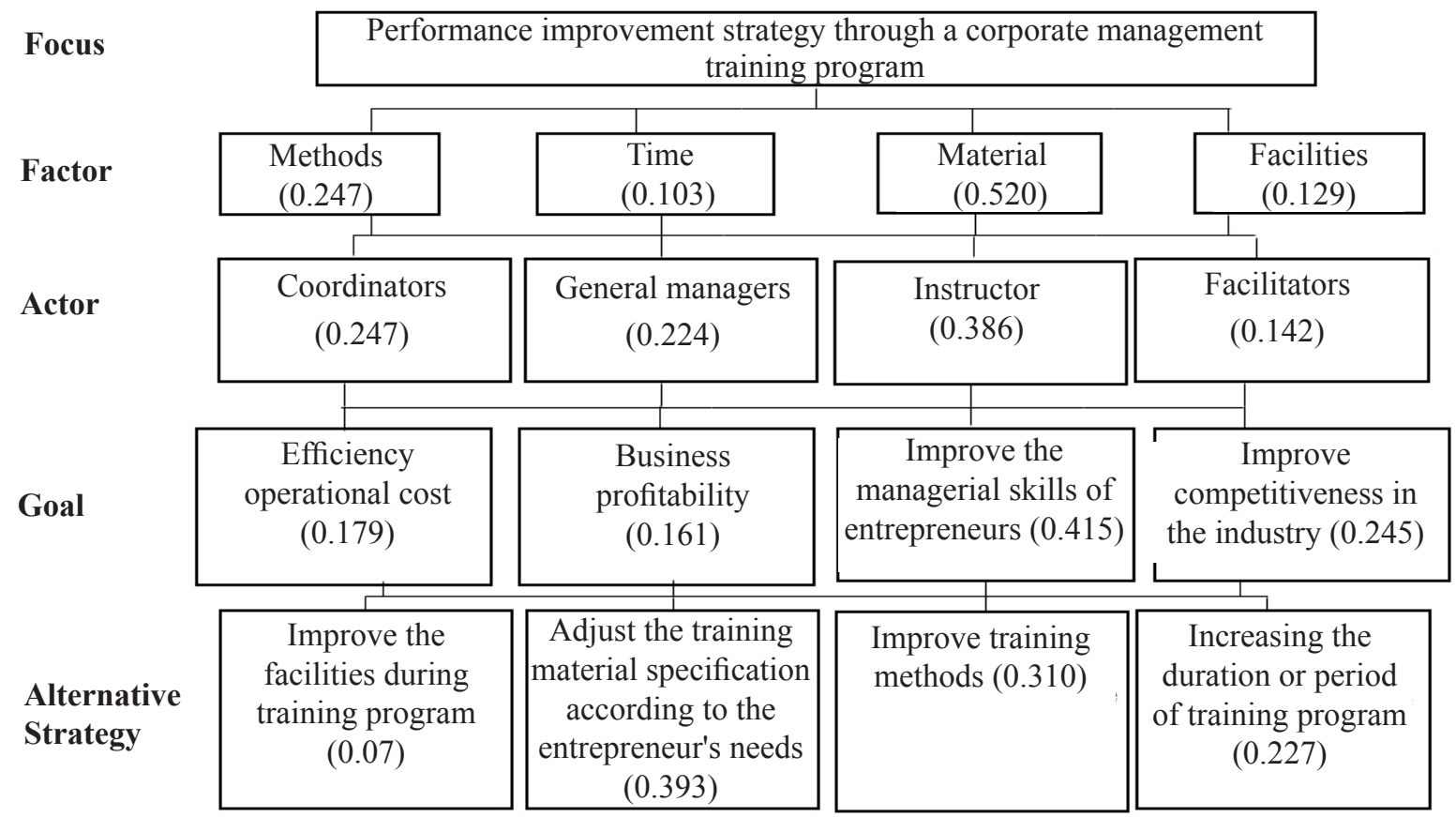

Figure 5. AHP Hierarchy Analysis Result 
- The instructor is the main priority in corporate management training. Therefore, Instructor needs to have a wide knowledge regarding the materials that will be delivered and also experienced in the entrepreneur industry so he or she can give a proper example to the training participant. Aside from that, the Instructor also needs to have good material delivery so the participant can understand his explanation. Coordinator and General Manager also need to support the Instructor activities during the training program, for example getting feedback from a participant regarding Instructor performance when giving training through a questionnaire or direct interview. The presence of the coordinator during the training program is also regarded as important because the coordinator can help Instructors or participants when they need information about the training program or other things outside the materials.

- In corporate management training goals, AOTS needs to give priority to one goal that is to increase the managerial performance of entrepreneurs. Because the main problem of YDBA Entrepreneurs is the lack of managerial ability that came from lacking knowledge or insight in properly managing their business. From these managerial skills improvements, it is expected that performance will be impacted then their business can sustain.

\section{CONCLUSIONS AND RECOMMENDATIONS}

\section{Conclusions}

The result of this research shows that the corporate management training program significantly and positively affects competency of YDBA entrepreneurs. The competency that is inside entrepreneurs' individuals is also affected by the training result they participated in. The result also shows that corporate management training influences the performance of YDBA entrepreneurs positively and significantly. By giving this corporate management training, YDBA entrepreneurs can arrange their work properly and they can make a precise decision and also solve issues their company faced. Aside from that, this research result finds that competency affects the performance of entrepreneurs. This can be seen from their skills, knowledge, the attitude of entrepreneurs can help them improve their performance.
The best strategy or the most prioritized strategy that can be implemented to increase the performance of YDBA entrepreneurs through corporate management training program is to adjust the material specification according to their needs through TNA. TNA is an initial step before conducting a training program and an important way to allocate training effectively (Schuler et al. 1993). There are three stages of TNA namely organizational analysis, operations analysis, and individual analysis (Cascio, 1992; Schuler et al. 1993). Under these steps, it will be clear what kind of material specification that YDBA entrepreneurs need. Because with the correct materials or topics which is currently faced by the entrepreneurs, then the result acquired from the training can be used properly by them. Proper material will also increase the training effectiveness because the reaction from the participant during training will be different if the material is not what they expected.

\section{Recommendations}

For further research, it can be developed by analyzing competencies and performances of the participant before and after training so that a different strategy can be created in deciding the most effective training strategy. The limitation of this study is the limited operational variable where only training on competency and performance of YDBA entrepreneurs were analyzed. Aside from that, researches can analyze the training needs or material specifications by using Training Need Analysis to YDBA entrepreneurs.

\section{REFERENCES}

Ataunur I, Ariyanto E. 2015. Pengaruh kompetensi dan pelatihan terhadap kinerja karyawan PT. Adaro Energy Tbk. Telaah Bisnis 16(2): 135-150.

Ayuningtyas D. 2016. Efektivitas pelatihan dalam meningkatkan kompetensi pengajar bintang pelajar [thesis]. Bogor: Institut Pertanian Bogor.

Cascio WF. 1992. Acetate Transparency Program to Accompany Managing Human Resources. US: McGraw Hill.

Fry RC. 2011. Evaluating the impact of electronic training on organizational performance in an SME food manufacturing environment [thesis]. US: Northcentral University.

Ghozali I. 2011. Aplikasi Analisis Multivariate Dengan Program SPSS. Semarang: Badan Penerbit 
Universitas Diponegoro.

Halawi A, Haydar N. 2018. Effects of training on employeeperformance. InternationalHumanities Studies 5(2): 24-45.

Hutapea P, Nurianna T. 2008. Kompetensi komunikasi Plus: Teori, Desain, Kasus dan Penerapan untuk HR dan Organisasi yang Dinamis. Penerbit: Gramedia Pustaka Utama, Jakarta.

Ishizaka A, Labib A. 2009. Analytic Hierarchy Process and Expert Choice: Benefits and limitations. $O R$ Insight 22(4): 201-220. https://doi.org/10.1057/ ori.2009.10.

Kirkpatrick DL, Kirkpatrick JD. 2006. Evaluating Training Program, 3rd edition. USA: BerrettKoehler Publisher, Inc.

Kirkpatrick JD, Kirkpatrick WK. 2016. Kirkpatrick's Four Levels of Training Evaluation. USA: ATD Press.

Kusbiantoro. 2015. Efektivitas pelatihan calon transmigran pada Balai Besar Pelatihan Ketransmigrasian Yogyakarta [thesis]. Yogyakarta: Gajah Mada University.

Sianturi ME. 2018. Pengaruh pelatihan dan pengembangan karir terhadap kinerja karyawan PTBank Mandiri ( Persero ) Tbk Cabang Imam Bonjol Medan [skripsi]. Medan: Universitas
Sumatera Utara.

Mukata CM, Ladzani W, Visser T. 2018. The effectiveness of business management and entrepreneurship training offered by SME service providers in Namibia. African Journal of Business and Economic Research 13(2): 8198. https://doi.org/10.31920/1750-4562/2018/ v13n2a 4 .

Nurjanah. 2006. Efektivitas program pelatihan bidang manajerial bagi karyawan PT Grand Textile Industry Bandung [thesis]. Bogor: Institut Pertanian Bogor.

Posuma C. 2013. Kompetensi, kompensasi, dan kepemimpinan pengaruhnya terhadap kinerja karyawan pada Rumah Sakit Ratumbuysang Manado. Jurnal EMBA 1 (4): 646-656.

Robbins S. 2006. Perilaku Organisasi, prentice hall, edisi kesepuluh. Jakarta: PT. Indeks.

Safitri E. 2013. Pengaruh pelatihan dan disiplin kerja terhadap kinerja karyawan. Jurnal Ilmu Manajemen (JIM) 1(4): 1044-1054.

Schuler RS, Vandra LH, Fenton. 1993. Personnel and Human Resource Management (5th. ed.). USA: West Publishing Co.

Sugiyono. 2006. Metode Penelitian Kuantitatif Kualitatif dan R\&D. Bandung: Alfabeta. 